\title{
SUSTAINABLE EXCHANGE RATES WHEN TRADE WINDS ARE PLENTIFUL
}

\author{
Jan Babecký,* Aleš Bulíř,** and Kateřina Šmídková*
}

Estimation and simulation of sustainable real exchange rates in a sample of EU member countries find vulnerabilities connected to the adoption of the euro if the rate vis-à-vis the euro were to be fixed with weak fundamentals and inappropriate policies. Sample countries have benefited from dramatic improvements in their external positions, in part driven by inflows of foreign direct investment. As a result, exchange rate misalignments have narrowed in most countries and, looking ahead, are expected to narrow further. These results are conditional, however, on optimistic projections with respect to world import demand and foreign direct investment inflows.

Keywords: Sustainable real exchange rates; foreign direct investment; ERM2

JEL Classifications: F3I; F33; F36; F47

\section{Introduction}

We find that exchange rate misalignments have narrowed in both the Euro Area and Central European countries, in part driven by inflows of foreign direct investment (FDI) and corresponding improvements in trade balances. The real exchange rate is deemed sustainable to the extent that net exports can support the long-term level of debt as real exchange rate appreciation/depreciation vis-à-vis its equilibrium level is reflected primarily in a larger/smaller accumulation of external liabilities. Looking ahead, further narrowing of exchange rate misalignment in sample countries is conditional on optimistic projections with respect to world import demand and foreign direct investment inflows. Overall, we find a more favourable picture as compared to our previous papers dealing with the estimation of sustainable real exchange rates, SRER. In Šmídková, Barrell, and Holland (2002), Bulíř and Šmídková (2005), and Bulíř and Šmídková (2007) we have found sizeable and growing misalignments in countries that participated in the Exchange Rate Mechanism (ERM2) ${ }^{1}$ in the late 1990s and early 2000s, such as Greece, Portugal, and Spain, and also in countries that were yet to adopt the euro at that time, such as the Czech Republic, Hungary, Poland, and Slovenia. Although FDI inflows were found to improve the trade balance, this effect was found to be too small in most countries under investigation.

The concept of a sustainable real exchange rate, which goes back to the research of Artus (1977), can be used for measuring the misalignment of a real exchange rate series. In the ERM2/Euro Area context the difference between an estimate of the SRER and the observed real exchange rate measures exchange rate misalignment for historic data and a conflict between the fixed exchange rate and the decreed inflation objective for projections. Our modelling approach reflects stylised facts of a small open economy that receives large capital inflows from its developed neighbours and converges rapidly both in real and nominal terms. In such an economy the real exchange rate developments are affected by foreign direct investment by stimulating aggregate supply and by raising permanent income. ${ }^{2}$ These two main channels of the impact of FDI on growth are well researched: first, through an increase in total investment and, second, through interaction of the FDI's more advanced technology with the host's human capital (Lim, 2001). To the extent that the latter channel affects sectoral productivity, it is akin to the Balassa Samuelson effect.

\footnotetext{
${ }^{*}$ Czech National Bank, e-mail: jan.babecky@cnb.cz, katerina.smidkova@cnb.cz. **International Monetary Fund, e-mail: abulir@imf.org. The authors acknowledge the support of colleagues at the National Institute of Economic and Social Research. The previous versions of the paper benefited from comments by Ignazio Angeloni, Carsten Detken, László Halpern, Katarina Juselius, Jan Kodera, Louis Kuijs, Kirsten Lommatzsch, Martin Mandel, Alessandro Rebucci and participants at seminars at the European University Institute, International Monetary Fund, Prague University of Economics, Czech National Bank and the European Central Bank. Views expressed in this paper are those of the authors and do not necessarily represent those of the Czech National Bank or the International Monetary Fund.
} 
This paper differs from and updates our previous attempts at the SRER estimation in several respects. First, we re-estimated the underlying export and import functions with a new set of data, reflecting the export boom in the mid-2000s. Second, we extended our sample to include Slovakia, which was expected to enter the Euro Area in 2009. Finally, we extended the cutoff point of the estimation to 2007, capturing the process of real and nominal convergence observed before and after the EU accession in the five new member countries in the sample. While the convergence process seems to have slowed down in the Euro Area sample countries, such as Greece, Portugal, Spain, and Slovenia, it continues unabated in the Czech Republic, Hungary, Poland and Slovakia.

We estimate the sustainable real exchange rates using a set of economic fundamentals: net external debt, the stock of net foreign direct investment, terms of trade, international interest rates, and domestic and external demand variables. Just like any model of equilibrium real exchange rates, this approach provides model specific results that differ from those based on alternative approaches. Our projections of sustainable real exchange rates for 2008-12 are conditional on the structure of our model and on macroeconomic projections from the National Institute Global Econometric Model (NiGEM), the IMF's World Economic Outlook (WEO) projections of foreign direct investment, and announced inflation targets. We ask what is likely to happen to the SRERs, had the sample countries fixed their exchange rates vis-à-vis the euro in the last quarter of 2007 and controlled inflation at the levels announced as their inflation targets by either the ECB for the Euro Area countries or by national central banks for the countries outside the Euro Area.

Under the Maastricht rules, to qualify for the euro, a country must achieve a high degree of price stability, keep its government finances sustainable (in terms of the public deficit and public debt), and maintain a stable exchange rate and convergence in long-term interest rates. In addition, before adopting the euro, a country must also have been a member of the ERM2 for a minimum of two years. These formal requirements are, however, insufficient to prevent macroeconomic difficulties if the parity vis-à-vis the euro was misaligned, the country pursued weak policies, or was hit by an adverse shock. Needless to say, domestic demand adjustment to rectify these disequilibria is costly, as demonstrated recently in Portugal (International Monetary Fund, 2006). The authorities can either adjust the exchange rate or, under a fixed regime, adjust macroeconomic and structural policies to expand the country's export capacity gradually by improving its competitiveness.

Euro adoption raises multiple questions. When is the period of nominal convergence over, so that pegging the domestic currency to the euro poses no risks? Do we see an exchange rate misalignment at present? Is it likely to widen or narrow, given the projected path of monetary policy? While all the currencies in our sample appreciated in real terms during the past decade, the pace was much faster in the group of latecomer countries and the observed appreciation contradicts the traditional nexus of external wealth accumulation of Lane and Milesi-Ferretti (2002), see figure 1. Contrary to the hypothesis that countries with sizable external liabilities need to run large trade balance surpluses to service these debts, all countries have piled up external liabilities and, at the same time, have run persistent trade deficits accompanied by real exchange rate appreciation. Current account deficits widened in the Euro Area countries (forerunners), while they improved somewhat in the latecomer countries.

New member countries, with the exception of Slovenia, have received massive inflows of foreign direct investment (FDI) that may have affected investors' perceptions about the countries' long-term sustainable external balances. Assuming that export growth and productivity improvements are driven by FDI, contemporaneous capital inflows may signal expected future net export gains consistent with appreciated real exchange rates. The simple relationship between the increase in the stock of FDI and improvements in the trade balance in goods is suggestive - countries with high levels of FDI accumulation export more than those with low levels of FDI accumulation, see figure 2. This hypothesis is consistent with previous empirical work related to foreign direct investment in transition countries (Lansbury et al., 1996, and Benáček et al., 2003).

The paper is organised as follows. Section 2 outlines an empirical model of sustainable real exchange rates, and explains its calibration. Section 3 presents our simulation results. Section 4 concludes.

\section{Empirical evidence}

We limit the normative target estimates of sustainable real exchange rates to four forerunners with a peg to the euro - Greece, Portugal, Slovenia, and Spain - and four 


\section{Figure I. Latecomers and forerunners: selected indicators, 1992-2007}

Forerunners: Real ERs $(1992=100)(a)$

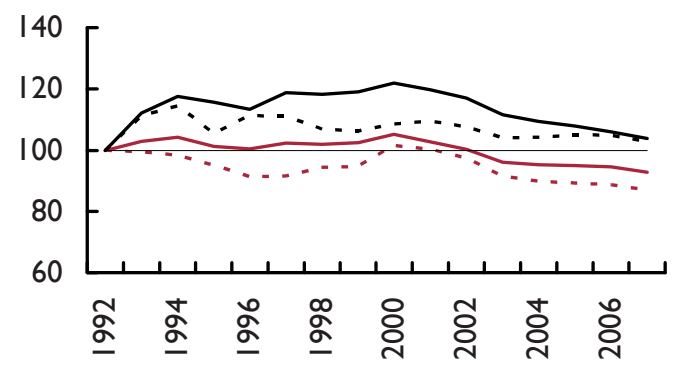

Forerunners: NFA (\% of GDP)

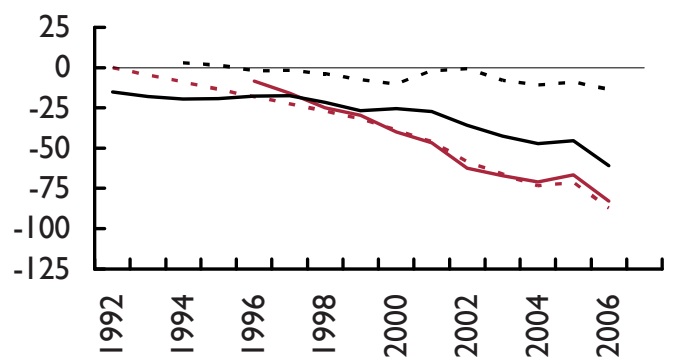

Forerunners: Stock of net FDI (\% of GDP)

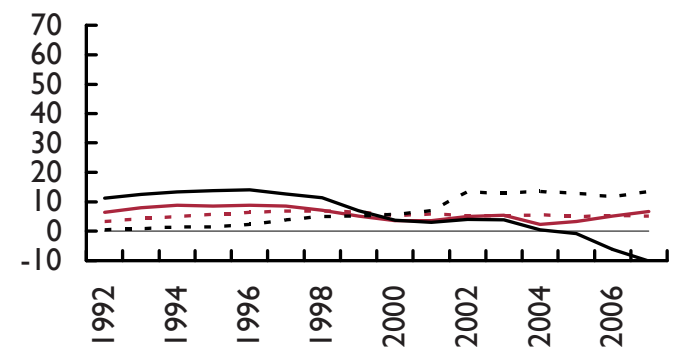

Forerunners: Current account (\% of GDP)
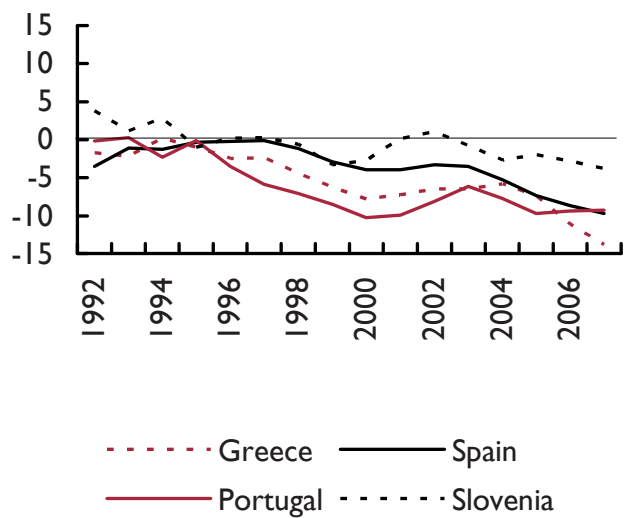

Latecomers: Real ERs $(1992=100)(a)$

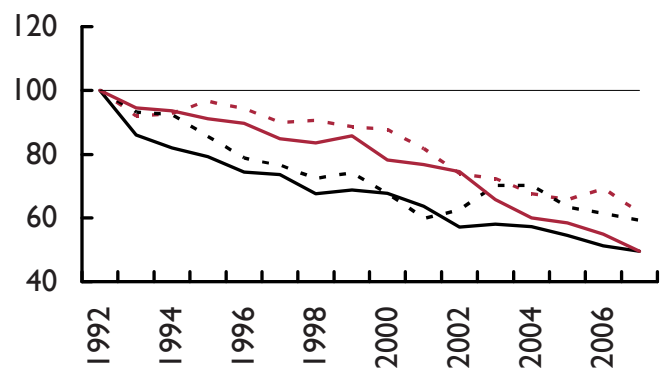

Latecomers: NFA (\% of GDP)

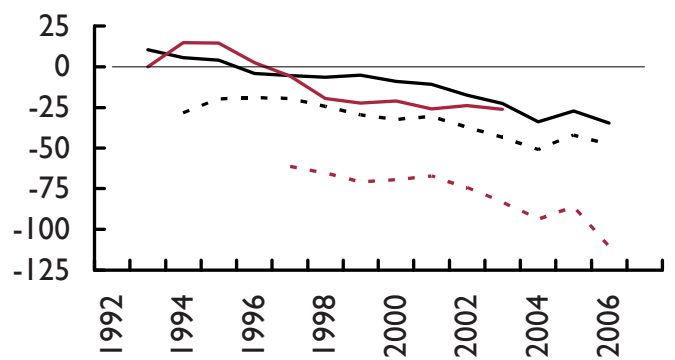

Latecomers: Stock of net FDI (\% of GDP)

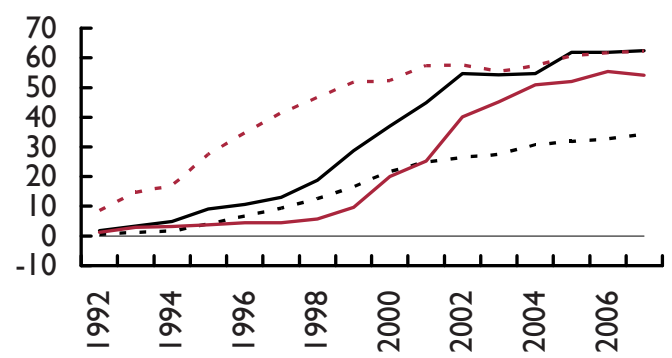

Latecomers: Current account (\% of GDP)
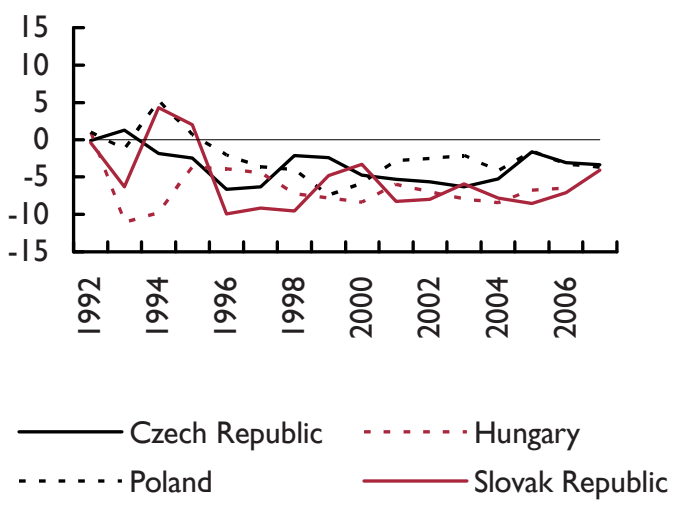

Source: World Economic Outlook, International Financial Statistics, NiGEM, authors' calculations. Note: (a) CPI-based real exchange rates. Observations above 100 are defined as an increase in competitiveness, that is, real depreciation vis-à-vis the base period. 
Figure 2. Foreign direct investment is paying off(a)

(Changes in net FDI and in the goods trade balance, \% of GDP)

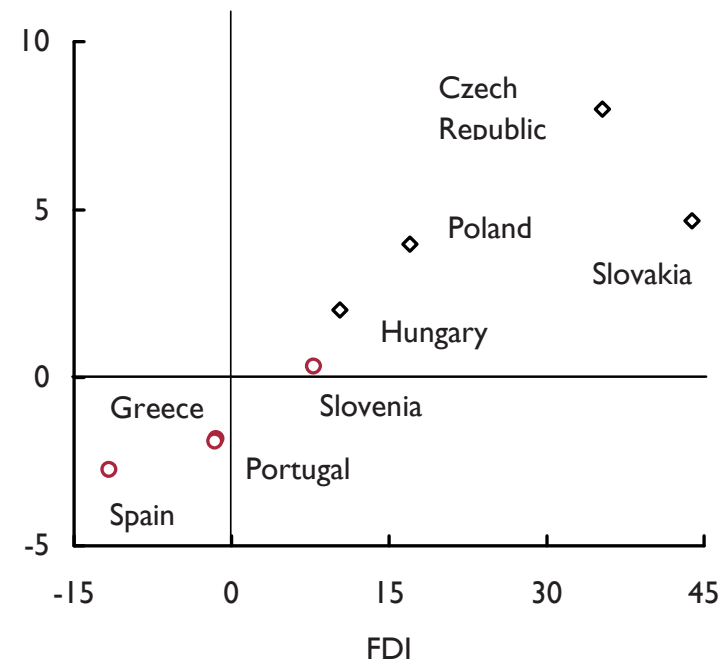

Source: World Economic Outlook, authors' calculations.

Note: (a) The horizontal axis shows the difference between the stock of net FDI-to-GDP ratio in 2003-7 and 1996-9. The vertical axis shows the difference between the average trade balance in goods as a ratio to GDP in 2003-7 and 1996-9.

latecomers with floating exchange rates - the Czech Republic, Hungary, Poland, and Slovakia. After outlining the empirical model, we rationalise our choice of calibrated parameters, and present the results. The selected approach defines the external balance in terms of stocks rather than flows and emphasises the role of foreign direct investment as the decisive factor in fundamental-based real exchange rate appreciation. The data are drawn from the NIESR and IMF databases.

\section{The SRER Model}

In our empirical simulations we take all future macroeconomic variables but FDI from the NiGEM database as projected under the assumption of flexible exchange rates, making three additional simplifying assumptions. First, the external debt path and trade flows are endogenous. Second, no feedback from real overvaluation to FDI, trade developments, or growth can take place. Third, we allow the misalignment vis-àvis the equilibrium rate to be long lasting.

The normative target, SRER framework has been built around econometric trade equations relating exports and imports to fundamental variables such as the real exchange rate, the terms of trade, external debt, and domestic and foreign economic activity. The SRER model differs from its predecessors in several aspects. First, the FDI driven integration gains are incorporated directly into the model in a manner similar to Égert and Lommatzsch (2003) and estimated in an error-correction framework. Second, the current account balance is not restricted, as it is asset and liability stocks, not flows, that define the external equilibrium. The sustainable level of external debt is defined according to openness to trade. Third, all variables exogenous to the SRER are modelled within an underlying model framework (NiGEM), ensuring consistency and interdependency. Fourth, inflation projections are based on announced inflation targets (table 1).

Exports, $X$, increase with the net stock of foreign direct investment, $F$, to approximate the integration gain. ${ }^{3}$ Exports also expand with foreign demand, $S$, and improvement in the relative price of domestic goods either through real depreciation or a terms-of-trade change, $R P X$ :

$$
\begin{aligned}
\Delta \ln \left(X_{i, t}\right) & =\alpha_{0, i}-\lambda\left[\ln \left(X_{i, t-1}\right)-\alpha_{1} \ln \left(R P X_{i, t-1}\right)\right. \\
& \left.-\alpha_{2} \ln \left(S_{i, t-1}\right)-\alpha_{3} \ln \left(F_{i, t-1}\right)\right] \\
& +\alpha_{4, i} \Delta \ln \left(R P X_{i, t}\right)+\alpha_{5, i} \Delta \ln \left(S_{i, t}\right)+\mathrm{e}_{i, t} .
\end{aligned}
$$

Demand for imports, $M$, is driven by domestic activity,

\section{Table I. Announced inflation targets}

\begin{tabular}{lcc} 
Country & \multicolumn{1}{c}{$2008-9$} & 2010 and beyond \\
\hline The Euro Area countries & Close, but less than 2 per cent & Close, but less than 2 per cent \\
Czech Republic & 3.0 per cent $( \pm I$ per cent) & 2.0 per cent $( \pm I$ per cent) \\
Hungary & 3.0 per cent $( \pm$ I per cent) & 3.0 per cent \pm I per cent) \\
Poland & 2.5 per cent $( \pm I$ per cent) & 2.5 per cent $( \pm I$ per cent) \\
Slovakia & Close, but less than 2 per cent & Close, but less than 2 per cent
\end{tabular}

Source: The websites of the European Central Bank, Czech National Bank, Magyar Nemzeti Bank, National Bank of Poland, and Slovak National Bank. 
$Y$, improvement in the relative price of domestic goods either through real depreciation or a terms-of-trade change, RPM, and the FDI stock:

$$
\begin{aligned}
\Delta \ln \left(M_{i, t}\right) & =\beta_{0, i}-\delta\left[\ln \left(M_{i, t-1}\right)-\beta_{1} \ln \left(R P M_{i, t-1}\right)\right. \\
& \left.-\beta_{2} \ln \left(Y_{i, t-1}\right)-\beta_{3} \ln \left(F_{i, t-1}\right)\right] \\
& +\beta_{4, i} \Delta \ln \left(R P M_{i, t}\right)+\beta_{5, i} \Delta \ln \left(Y_{i, t}\right)+\mathrm{u}_{i, t} .
\end{aligned}
$$

The trade balance, external borrowing, and net external debt interest payments determine the level of net external debt in any given period. External debt, however, is not an unbounded variable - for a given rate of growth and initial real exchange rate a unique path of sustainable external debt is predetermined. At the same time, accession countries try to exploit fully the manoeuvering space of sustainable debt, as FDI inflows bring about the integration gain. In the SRER framework the path of sustainable debt can be approximated by considering the initial stock of debt and the country specific sustainable debt target for the end of the simulation period.

To the extent that it is not possible to determine the debt target within the underlying model, we base the targets on selected measures of external sustainability:

$$
D^{*}=\delta\left[D_{0}, D_{T}\right],
$$

where $D^{*}$ denotes the sustainable path of net external debt (in the domestic currency, ratio to GDP), and $D_{0}$ and $D_{\mathrm{T}}$ are the initial and target levels of net external debt.

A solution for sustainable real exchange rates reflecting the above economic fundamentals can be found simultaneously using equations (1-3):

$$
\begin{aligned}
& {\left[\bar{M} \cdot \beta_{0} \cdot\left(C^{*}\right)^{\beta_{1}} \cdot Y^{\beta_{2}} \cdot F^{\beta_{3}}-\bar{X} \cdot \alpha_{0} \cdot\left(C^{*}\right)^{\alpha_{1}} \cdot\left(\frac{P_{x}}{P_{m}}\right) \cdot S^{\alpha_{2}} \cdot F^{\alpha_{3}}\right]} \\
& =(1-r) D^{*} \cdot Y-D_{-1}^{*} \cdot Y_{-1}
\end{aligned}
$$

where $C^{*}$ is the sustainable real exchange rate; $\bar{M}$ and $\bar{X}$ are the volumes of real imports and exports in the base year, respectively; and $r$ is the world real interest rate.

\section{Parameter calibration}

The parameters used in equation (4) have been calibrated using panel data regression results from table 2, departing from the calibration used in Šmídková, Barrell, and Holland (2002), Buliř and Šmídková (2005) and (2007) that relied on panel data results from Barrell et al. (2002) and Šmídková et al. (2002). Equations (1) and (2) have been estimated in a panel comprising the four forerunner countries of Greece, Portugal, Spain, and Slovenia where trade developments now seem past the period of fast transitional growth. The panel long-term export and import elasticities have then been applied to calculate sustainable exchange rates in the Czech Republic, Hungary, Poland, and Slovakia on the assumption that the trade relationships are likely to settle at the forerunners' levels. The relative price elasticities are in line with earlier research and the integration gain

Table 2. Calibrated coefficients

Export equation

Coefficient

Real exchange rate elasticity of exports Foreign demand elasticity of exports(a)

FDI (stock) elasticity of exports

Speed of adjustment to long-run equilibrium

$\begin{array}{ll}\alpha_{1} & 1.95^{* * *} \\ \alpha_{2} & 1.00 \\ \alpha_{3} & 0.18^{* * *} \\ \gamma & 0.04 * * \\ \mathrm{R}^{2} & 0.48\end{array}$

Import equation

\begin{tabular}{lll}
\hline Real exchange rate elasticity of imports & $\beta_{1}$ & $-2.10 * * *$ \\
Domestic demand elasticity of imports(a) & $\beta_{2}$ & 1.00 \\
FDI (stock) elasticity of imports & $\beta_{3}$ & $0.08^{* *}$ \\
Speed of adjustment to long-run equilibrium & $\delta$ & $0.06 * * *$ \\
& $\mathrm{R}^{2}$ & 0.57
\end{tabular}

Note: (a) The unitary values of demand elasticities are imposed. ***, ** and $*$ denote significance levels at I per cent, 5 per cent, and 10 per cent respectively. 


\section{Table 3. Net external debt targets}

\begin{tabular}{lcc} 
Country & Exports-to-GDP ratio (\%) & External debt target \\
\hline The Czech Republic, Hungary, & Higher than 40 & 65 \\
Slovakia, Slovenia & Higher than 30, but lower than 40 & 53 \\
Poland, Greece, Portugal, Spain & Po & \\
\hline
\end{tabular}

Source: Authors' calculations based on International Monetary Fund (2002).

Table 4. Definition of variables

\begin{tabular}{lll} 
Variable & Notation & Data Source \\
\hline Effective foreign import demand (in millions of US dollars) & $S$ & NiGEM, January 2008 \\
Effective world real interest rate (in per cent) & $r$ & NiGEM, January 2008 \\
Import prices (index) & $P_{m}$ & NiGEM, January 2008 \\
Export prices (index) & $P_{x}$ & NiGEM, January 2008 \\
US dollar exchange rate (in domestic currency terms) & $E$ & NiGEM, January 2008 \\
Real domestic output (in constant prices) & $Y$ & NiGEM, January 2008 \\
Real exports (volume) & $X$ & NiGEM, January 2008 \\
Real imports (volume) & $M$ & NiGEM, January 2008 \\
Domestic consumer price index (CPI) & $P$ & NiGEM, January 2008 \\
Initial level of external debt (in millions of US dollars) & $D_{0}$ & NiGEM, January 2008; and Rider (I994) \\
Stock of FDI (in per cent of GDP) & FDI & IMF World Economic Outlook, January 2008; \\
Net external debt target for time T (T =2022; & & and IMF IFS, January 2008; (a) \\
in per cent of GDP) & $D^{*}$ & Calculations based on International Monetary \\
\hline
\end{tabular}

Note: (a) Calculations based on IMF WEO projections of FDI flows and initial estimates of the FDI stock consistent with the estimate of the initial stock of net foreign assets (NFA).

$\left(\alpha_{3}>\beta_{3}\right)$ is significant: a 1 percentage point increase in the stock of FDI increases long-run net exports by about 0.1 per cent.

We incorporate a trade based, country-specific definition of the net external debt target, values of which are binding in 2022 (table 3), whereas the earlier models assumed a fixed target equal to 60 per cent of GDP (Ades and Kaune, 1997). Recent events have shown that the rule of thumb approach may not be flexible enough. Sustainable external debt ought to be related to countries' ability to service it (International Monetary Fund, 2002), and uncertainty related to the target can be large. Nevertheless, the impact of changes in the sustainable debt to GDP ratio on the SRER estimates is relatively small: a 10 percentage point change in the ratio generated a change in the equilibrium real exchange rate of $0.04-0.4$ per cent only (Bulír̆ and Šmídková, 2005).

\section{Data issues and simulation techniques}

Data consistency is crucial for the SRER calculations, given the endogenous relationship between various variables, such as domestic and foreign demand or trade and financial flows. We rely on the global econometric model (NiGEM) maintained by the National Institute of Economic and Social Research, which allows us to project domestic and external variables within the same model (table 4). Our model experiment is based on an unconditional forecast - we implicitly assume that the NiGEM projection represents the optimal trajectory of macroeconomic developments.

We solved equations 1-4 in the WinSolve 3.0 (2003) simulation package, using the Newton procedure. For each country, baseline SRERs are calculated by solving equation (4) for the period 1995Q1-2012Q4. Input variables are set equal to the observed values for the insample computations (1995Q1-2007Q3) and to the forecast values for the out-of-sample computations (2007Q4-2012Q4).

\section{Empirical results}

We interpret the difference between an estimate of the SRER and the observed real effective exchange rate in two ways. First, for historic data the differential 
measures exchange rate misalignment conditional on our model and its calibration. Second, for the post-2007 fixed exchange rate regime the differential measures a conflict between the fixed exchange rate and the decreed inflation objective, conditional on our model and NiGEM and IMF projections. We discuss these measures in turn.

\section{Misalignment}

For 1998-2007 we compare our SRER estimates with observed values of effective real exchange rates and our estimates suggest that, first, forerunners' currencies were mostly overvalued and, second, latecomers' currency misalignments were volatile, with a gradual overvaluation trend towards the end of the period (see figure 3). ${ }^{4}$

In the forerunner countries, the drachma and peseta appreciated in excess of the estimated equilibrium level in 2001-2 and remained modestly overvalued, by less than 5 per cent, until the end of 2007. The escudo shows the largest misalignment, with overvaluation in excess of 10 per cent in 2002-4. Portuguese exports increased together with net FDI in the mid-2000s and the equilibrium rate appreciated, bringing the escudo to its equilibrium in late 2007. Slovenia adopted the euro only in January 2007, some eight years after Spain and Portugal, just in time to experience so far a minor real overvaluation.

In the latecomer countries exchange rate misalignments were substantially more volatile than in the forerunner countries as a result of both nominal exchange rate volatility and unsettled inflation. The Czech and Slovak korunas became overvalued from 2006 due to fast nominal appreciation and despite robust export growth that caused equilibrium appreciation of their currencies in our model. The forint, which was substantially overvalued in 2003-5, depreciated in nominal terms in 2006. In summary, these results signal potential overvaluation problems should these countries adopt the euro immediately. The zloty, which was substantially overvalued early in the decade, appears undervalued from late 2006, mostly on the back of solid export performance and limited accumulation of foreign liabilities.

The challenge forward: the joint exchange rate and inflation objectives

For post-2007 series we compare our SRER estimates with a real effective exchange rate commensurate with a peg to the euro and inflation equal to the announced inflation targets (see the forecast portion of figure 3).
Figure 3. Real effective exchange rates relative to equilibrium $^{(a)}$

(Percentage deviation from the SRER)

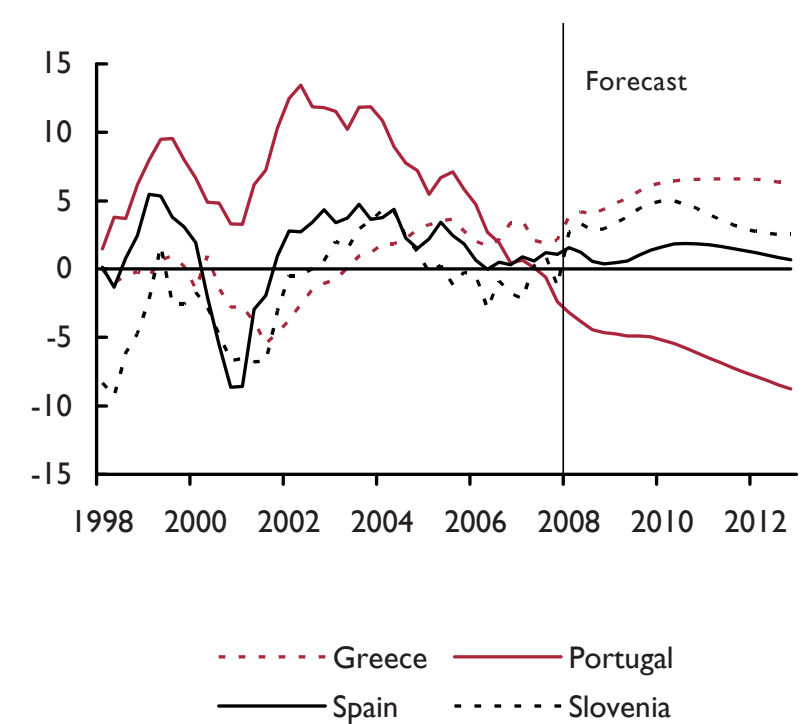

Latecomers
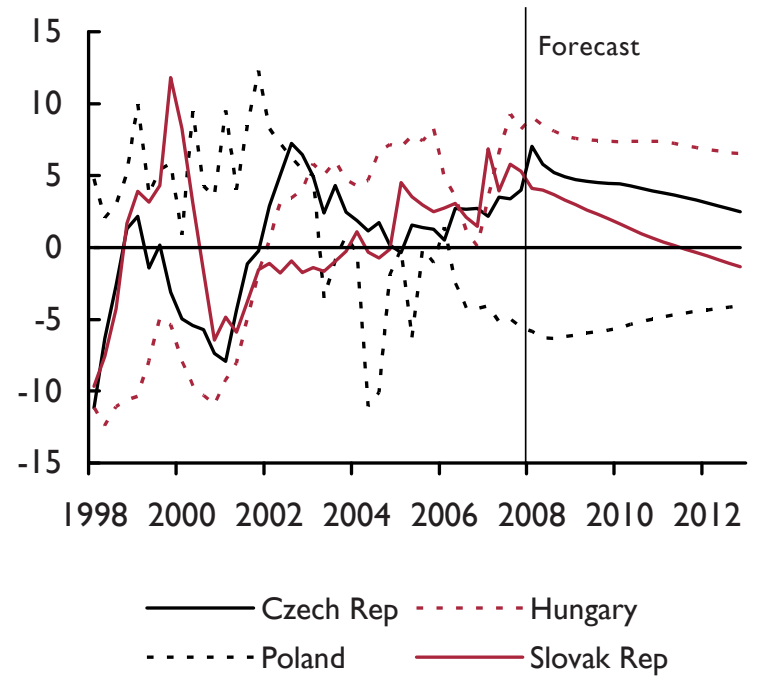

Source: Authors' calculations.

Note: (a) Misalignments for 2007Q4-2012Q4 are calculated using the announced inflation targets. Positive values imply real overvaluation visà-vis the sustainable exchange rate.

The difference between these two variables indicates how well the domestic economy has adjusted to the euro. If the real exchange rate projection exceeds the estimated SRER, then the real exchange rate that is equivalent to the peg and inflation target is too strong for the domestic economy to stay in external balance. 
Figure 4. Equilibrium appreciation when trade winds are plentiful(a) (Normalised estimates of sustainable real exchange rates, different vintages)

Greece

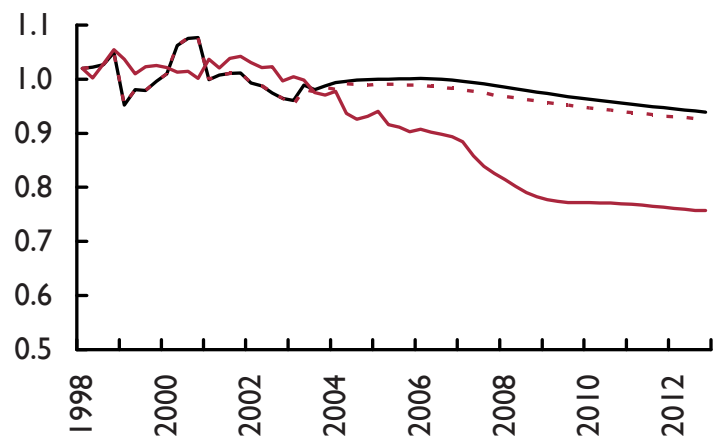

Portugal

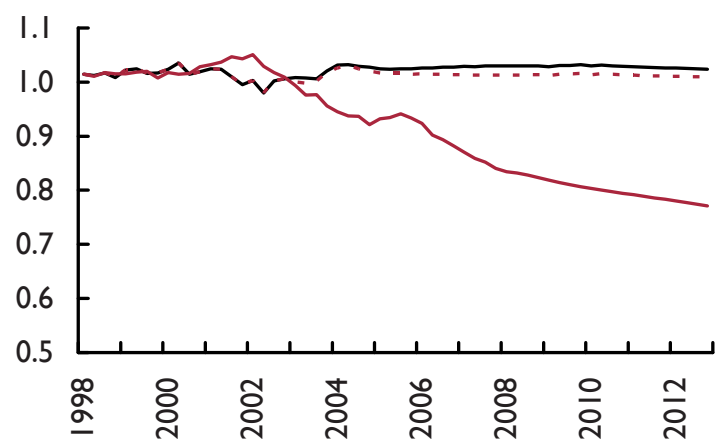

Spain

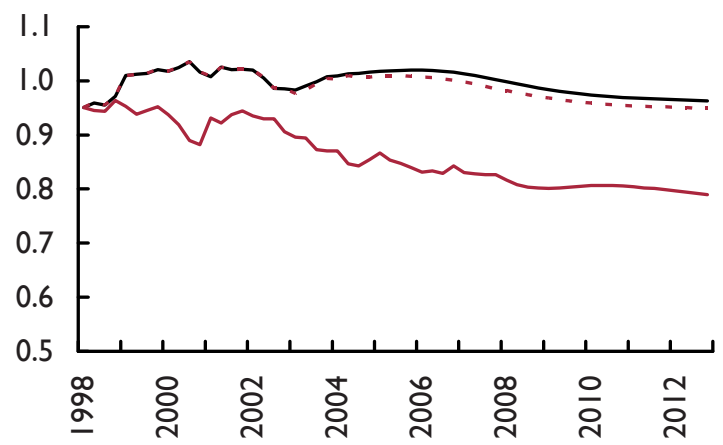

Czech Republic

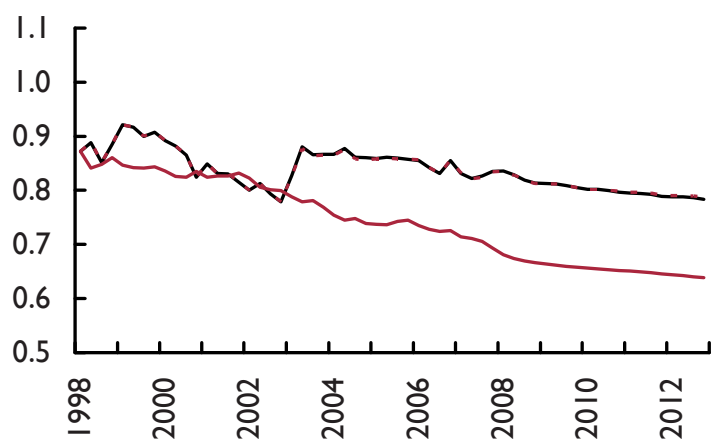

Hungary

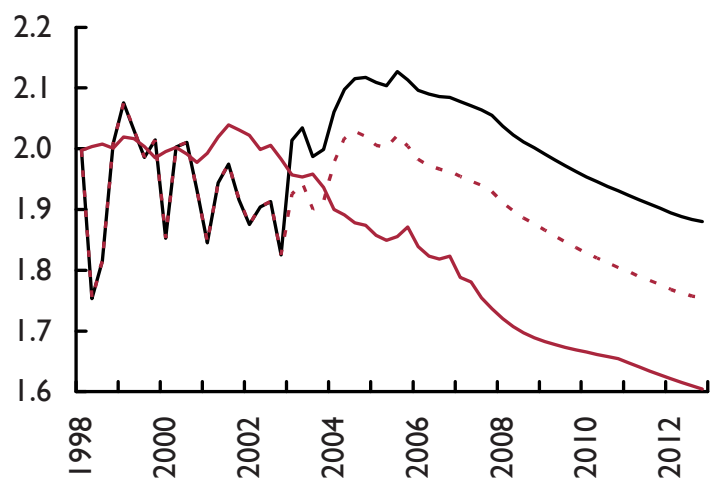

Poland

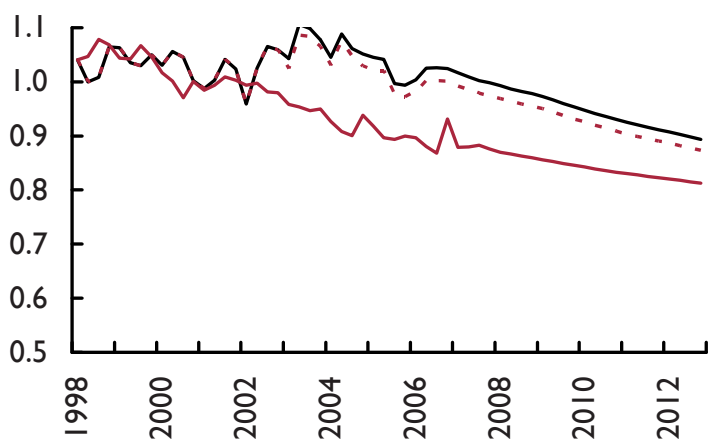

Note: (a) The 2003 (-), 2005 (---) and 2008 (-) vintages are based on Bulír and Šmídková (2005) and (2007), and this paper, respectively. Note that the estimates of the SRER levels are normalised and that we are interested in the slopes only.

Our measure of the conflict between the objectives of euro membership and external balance in the forerunner countries suggests the following. The drachma is expected to continue to appreciate above and beyond its equilibrium value, as the euro remains too strong for the Greek economy, mostly on account of sluggish Greek exports. The tolar and peseta are expected to remain close to the equilibrium value during the forecast period. 
More surprisingly, our results suggest that the Portuguese economy may have turned the corner and the escudo will have become undervalued to the tune of almost 10 per cent after the estimated double-digit real overvaluation in the early 2000s.

In the latecomer countries we observe that the conflict between the two objectives continues unabated in Hungary, with a magnitude of 5 per cent or more for the period under consideration, and hence the country would have difficulty sustaining the euro. The Czech and Slovak korunas both appear overvalued - to the tune of about 5 per cent at the start of the forecast period - but the gap is expected to narrow by 2012 . The zloty appears undervalued, but the real exchange rate is also projected to narrow the gap by the end of the forecast period.

\section{Robustness checks}

The estimates of equilibrium exchange rates obtained in this round are more favourable than those from the two earlier (normalised) SRER estimates in Bulír and Šmídková (2005) and (2007), see figure 4. Among the forerunner countries, the equilibrium appreciation in the escudo is quite pronounced. However, both the drachma and peseta seem better able to withstand the euro than when estimated earlier. The equilibrium appreciation in the latecomer countries continues at about the same speed as before - the gradual net export slowdown projected earlier in the NiGEM series, which was causing much slower equilibrium appreciation in earlier vintages of the SRER estimates, did not materialise. Given that levels of the SRER estimates were normalised, we focus on the slopes of the estimated SRER series as the levels are not directly comparable.

The major differences in the current vintage of the SRERs as compared to our earlier estimates are (i) new calibrations of the trade equations and (ii) new sets of projections for macroeconomic variables from NiGEM, and (iii) FDI flows from the IMF World Economic Outlook that we use to build the net stocks of FDI. Also, it should be noted that the period from about 2003 to 2007 was quite advantageous to our sample countries. The Euro Area and especially the fast converging nonEuro Area countries benefited from robust demand for their exports and benign inflation developments that kept price competitiveness unchanged.

Are such benign developments likely to persist in the future? First and foremost, all sample countries benefited from increased demand for their goods and services and managed to either stabilise or improve their export position. Net export performance in the non-Euro Area countries was exceptionally good and a pronounced slowdown in the world economy will affect demand for small member country exports and thus also their equilibrium exchange rates. Second, the FDI inflows show signs of ebbing, generating two processes, both of which will negatively affect the competitiveness of domestic economies. On the one hand, it would depreciate the SRER, hence increasing the gap between the equilibrium real exchange rate and the rate commensurate with a peg to the euro and inflation target. On the other hand, it would limit the expected integration gain, restricting real convergence and abating or reversing the export boom in the latecomer countries, thus depreciating the SRER even more.

\section{Conclusions}

Using an updated model of sustainable real exchange rates we find that exchange rate misalignments have narrowed in both the Euro Area and Central European countries, in part driven by inflows of foreign direct investment and corresponding improvements in trade balances. Looking ahead, some further narrowing of exchange rate misalignment in our sample countries is conditional on optimistic projections with respect to world import demand and foreign direct investment inflows. In comparison with previous vintages of our SRER estimates, we find that equilibrium appreciation is proceeding faster than projected earlier, mostly due to much faster net export growth recorded during 2003-7. In turn, this makes the current projections vulnerable to any worsening of external conditions. Nevertheless, even under these benign conditions, the euro is projected to remain too strong for most of the economies in our sample.

\section{NOTES}

I The European exchange rate mechanism (ERM) was a system introduced by the European Community in March 1979, as part of the European Monetary System (EMS), to reduce exchange-rate variability and achieve monetary stability in Europe, in preparation for Economic and Monetary Union and the introduction of a single currency, the euro. In 1999, ERM2 replaced the original ERM. The Greek and Danish currencies were part of the ERM2, but as Greece joined the euro in $200 \mathrm{I}$, the Danish krone was left as the only participant member. Following EU membership, the Cyprus pound, Estonian kroon, Latvian lats, Lithuanian litas, Maltese lira, Slovak koruna, and Slovenian tolar were included in the ERM2 at various dates. The pound, lira, and tolar were eventually replaced by the euro after a successful ERM2 test. During that period one currency, the litas, had its euro application rejected. 
2 See Appendix in Bulír, A. and Šmídková, K. (2005) for the algebraic solution of the model. The model does not incorporate any common currency effect on trade and income (Bun and Klaasen, 2002) as the integration of the accession countries with their EU trading partners has progressed towards the EU levels. Therefore, a common currency is itself unlikely to bring a major integration gain.

3 We are aware that the impact of FDI can differ from country to country, depending in the short run on the import component of FDI and in the medium term on whether the new technology produces exportable goods or substitutes for imported goods. Moreover, measurement problems persist in the sample countries with respect to the recording of various FDI components, such as reinvested profits.

4 Positive values imply overvaluation vis-à-vis the SRER estimates, negative values imply undervaluation.

\section{REFERENCES}

Ades, A. and Kaune, F. (1997), 'A new measure of current account sustainability for developing countries', Goldman-Sachs Emerging Markets Economic Research.

Artus, J. (1977), 'Methods of assessing the long run equilibrium value of an exchange rate', IMF Working Paper, WP/77/I24, Washington, DC, International Monetary Fund.

Barrell, R., Holland, D., Jakab, Z.M., Kovács, M.A., Šmídková, K., Sepp, U. and Ėufer, U. (2002), 'An econometric macro-model of transition: policy choices in the pre-accession period', in Proceedings of AMFET'200 I Conference - Modelling Economies in Transition, Krag (Poland), Lodz, Absolwent.

Benáček, V., Prokop, L. and Víšek, J.A. (2003), 'Determining factors of the Czech foreign trade balance: structural issues in trade creation', CNB Working Paper, 3/2003, Prague, Czech National Bank.
Bulír, A. and Šmídková, K. (2005), 'Exchange rates in the new EU accession countries: what have we learned from the forerunners?', Economic Systems, 29, pp. 163-186.

-(2007), 'Fast sailing toward the euro: dangers of the lee shore', in Batini, N., Monetary Policy in Emerging Markets and Other Developing Countries, New York, Nova Science Publishers.

Bun, M.J.G. and Klaasen, F. J.G.M. (2002), 'Has the euro increased trade?', Tinbergen Institute Discussion Paper, TI 2002 I08/2, Amsterdam, Tinbergen Institute.

Égert, B. and Lommatzsch, K. (2003), 'Equilibrium real exchange rates in acceding countries: how large is our confidence (interval)?, Focus on Transition, 7, pp. 107-37.

International Monetary Fund (2002), Assessing Sustainability, Washington, DC, International Monetary Fund.

-(2006), 'Portugal: selected issues', Country Report No. 06/386, Washington, DC, International Monetary Fund.

Lane, P.R. and Milesi-Ferretti, G.M. (2002), 'External wealth, the trade balance, and the real exchange rate', European Economic Review, 46, Pp. I049-7I.

Lansbury, M., Pain, P. and Šmídková, K. (1996), 'Foreign direct investment in central Europe since 1990: an econometric study', National Institute Economic Review, I56, pp. I04-I4.

Lim, E.-G. (200I), 'Determinants of, and the relation between, foreign direct investment and growth: a summary of the recent literature', IMF Working Paper, WP/0 I/I75, Washington, DC, International Monetary Fund.

Rider, M. (1994), 'External debt and liabilities of industrial countries', RBA Research Discussion Paper 9405, Sydney, Reserve Bank of Australia.

Šmídková, K., Barrell, R. and Holland, D. (2002), 'Estimates of FRERs for the five EU accession countries', CNB Working Paper, No. 3, Prague, Czech National Bank.

WinSolve (2003), Version 3, A computer package for solving nonlinear models, available via the Internet: http:// www.econ.surrey.ac.uk/winsolve/. 